\title{
Knowledge of, attitudes to and participation in clinical trials in Jordan: a population-based survey
}

Mamoun Ahram, ${ }^{1}$ Ala'a Farkouh, ${ }^{2}$ Marah Haddad, ${ }^{2}$ Zeina Kalaji ${ }^{2}$ and Ahmad Yanis ${ }^{2}$

${ }^{1}$ Department of Physiology and Biochemistry, The University of Jordan, Amman, Jordan. ${ }^{2}$ School of Medicine, The University of Jordan, Amman, Jordan. (Correspondence to: Mamoun Ahram: m.ahram@ju.edu.jo; Dr.Ahram@gmail.com).

\begin{abstract}
Background: Clinical trials are important to improve public health care. However, recruiting participants for trials can be difficult.

Aims: This study assessed public knowledge of and willingness to participate in clinical trials in Jordan and examine the sociodemographic characteristics associated with knowledge and willingness and the reasons behind unwillingness to participate.

Methods: The questions were part of a representative, population-based survey in 2011 that included 3196 Jordanian individuals. In a home-based interview, participants were asked about: sociodemographic characteristics, and knowledge of and participation in clinical trials

Results: Only $21.8 \%$ of respondents knew what a clinical trial was and (1.2\%) had participated in a trial. About $25 \%$ of respondents indicated their willingness to enrol in a trial. Significantly more men (24.1\%) than women (19.3\%) knew what clinical trials were $(P<0.001)$, whereas more women $(4.3 \%)$ than men $(2.9 \%)$ said they would be very likely to agree to participate in trials. People aged 40-49 years had better knowledge of and greater willingness to participate in trials than other age groups. Income was positively associated with knowledge of trials but negatively associated with willingness to participate. Higher education was positively correlated with knowledge of and willingness to take part in trials. The main reasons for not participating in trials were concern about the risk to own health $(61.1 \%)$ and not being convinced about the outcome and benefits of clinical trials (29.7\%).

Conclusion: The low level of knowledge of and willingness to participate in clinical trials indicates that strategies are needed to educate the public about the nature and importance of clinical trials.
\end{abstract}

Keywords: clinical trials, attitudes, public health, Jordan

Citation: Ahram M; Farkouh A; Haddad M; Kalaji Z; Yanis A. Knowledge of, attitudes to and participation in clinical trials in Jordan: a population-based survey. East Mediterr Health J. 2020;26(5):539-546. https://doi.org/10.26719/2020.26.5.539

Received: 23/04/18; accepted: 14/10/18

Copyright (c) World Health Organization (WHO) 2020. Open Access. Some rights reserved. This work is available under the CC BY-NC-SA 3.0 IGO license (https://creativecommons.org/licenses/by-nc-sa/3.o/igo).

\section{Introduction}

Clinical trials are important for the continuing growth of medical knowledge and health care. Economically, they also create many jobs in the health care, pharmaceutical and research fields and contribute to increased profits for companies involved and national institutions (1-3). However, recruiting participants for clinical trials is not easy. This is an important problem given that participation of varied groups is necessary to understand how successful an intervention is and the factors that affect this success $(4,5)$.

International efforts have long been underway to determine public perception of clinical trials and the factors that influence participation. In Australia, a qualitative study interviewing breast cancer patients showed poor knowledge of the importance and process of clinical trials (6). In Japan, trust in doctors was shown to have a considerable role in participation, and the concepts of placebo, randomization and double-blind trials were perceived adversely (7). Results of a study in Denmark showed a more positive attitude to clinical trials, however, the study concluded that fear of the unknown and unease with randomization were the most common reasons for not participating (8). Regionally, in Saudi Arabia, most participants in a study were aware of clinical trials but had several misconceptions about them and an uncooperative attitude (9). On the other hand, a study in Oman reported low levels of knowledge of clinical trials (10). All the aforementioned studies highlighted the importance of education on and increased awareness of clinical trials among the general public. Studies in the United States of America (USA) have shown that women, people aged more than 65 years, people of low socioeconomic status, African Americans and other non-white ethnicities are underrepresented populations in cancer studies (11-13). In Jordan, no studies on the public's knowledge and perception of clinical trials have been conducted.

In order to develop a strong platform of clinical trials in Jordan, it is important to understand the factors that determine public participation in clinical trials, including people's knowledge of clinical trials, likelihood 
to participate and reasons for not participating, and the effects of sociodemographic factors on these factors. Understanding these factors will allow stakeholders to determine the best approach for the health care system to encourage more clinical trials and to encourage people's participation. As Jordan has a similar cultural background as other Middle Eastern countries, findings from our study could also guide initiatives on clinical trials in nearby countries.

\section{Methods}

\section{Study design}

The questions on clinical trials were part of a wider quantitative cross-sectional survey entitled "Knowledge, attitudes, practices towards cancer prevention and care in Jordan" (14). This survey was conducted at the national level and consisted of 10 sections, one of which was on new fields of cancer research in Jordan. In this section, public knowledge of and attitudes to clinical trials were assessed. More details about the survey can be found elsewhere (15-17).

\section{Participants and procedures}

The survey was conducted nationwide in the three regions of Jordan (North, Central and South) covering the 12 governorates. The survey sample was selected using the 2004 Population and Housing Census as the sampling frame in order to ensure that the final sample reflected the socioeconomic and geographic composition of Jordan. Participants were approached by college-educated, trained, female interviewers in their homes. Face-to-face interviews were held with 3196 individuals aged 18 years and more from January to March, 2011. Selected houses were re-visited twice before excluding them; about $5 \%$ of houses were excluded.

\section{Data collection}

Data were collected using a questionnaire in Arabic, with an available English translation, when needed. International references/tools, such as the Health Information National Trends Survey (18), were used to guide the development of the questionnaire. The questionnaire was adapted to the local context and was reviewed by the advisory committee of the knowledge, attitudes, practices survey (15-17), the research team from Center of Consultation at the University of Jordan and experts from the Jordanian Department of Statistics, in order to ensure content validity and clarity.

Participants were asked about the following: (i) sociodemographic characteristics - sex, age, education level, marital status and income; (ii) their knowledge of clinical trials (yes/no); (iii) their previous participation in clinical trials after explaining what they were (yes/no); (iv) the likelihood that they would be willing to participate in clinical trials (measured on a 4-point Likert scale - very likely, likely, unlikely, very unlikely); (v) perceived health status (excellent, very good, good, satisfactory and bad); and (vi) reasons for not wanting to participate in clinical trials for those not willing (open-ended question).

\section{Statistical analysis}

Data were analysed using SPSS, version 17.0. Descriptive statistics were used to report sample characteristics. Categorical variables are presented as frequencies with corresponding percentages. Chi-squared analyses were used to examine the strength of the association between the independent variables (age, sex, educational level, marital status and income) and the main outcome variables of interest (knowledge of and participation in clinical trials and likelihood of agreeing to participate in one). In addition, the association between self-perceived health status and willingness to participate in clinical trials was assessed. The Pearson correlation coefficient ( $r$ ) was used to assess the relationship between sociodemographic characteristics and attitudinal statements.

\section{Ethical considerations}

Ethical approval for the study was obtained from a special committee at the Center of Consultation at the University of Jordan.

Before the interview, participants were briefed about the purpose and outcomes of the study, and their right to voluntarily participate, withdraw or refuse to participate. Verbal informed consent was obtained (agreement of the participants to be interviewed in their houses was considered as consent).

\section{Results}

\section{Sociodemographic characteristics of participants}

A total of 3196 respondents were included in the analysis for this report. Just over half $(51.5 \%)$ of the participants were men and $78.4 \%$ were under 50 years (Table 1 ).

\section{Knowledge of and participation in clinical trials}

When asked whether they had ever heard or read about clinical trials, only $21.8 \%$ of respondents had some knowledge of the term (Table 1), with significantly more men having knowledge of clinical trials than women $(24.1 \%$ versus $19.3 \%$ respectively, $P<0.001)$. In addition, significantly more respondents aged 40-49 years knew about clinical trials than those in other age groups $(P<0.001)$. Higher educational level $(r=0.178, P<0.001)$ and income $(\mathrm{r}=0.137, \mathrm{P}<0.001)$ were also positively associated with increasing knowledge of clinical trials.

After informing survey participants of the definition of a clinical trial, they were asked if they had ever participated in a trial. As expected, most respondents (98.8\%) indicated that they had never participated in a clinical trial with only $1.2 \%$ of them confirming their participation. No association was found between participation in clinical trials and age, education, sex and income (Table 2). 


\begin{tabular}{|c|c|c|c|c|}
\hline $\begin{array}{l}\text { Have you ever heard or read about } \\
\text { clinical trials? }\end{array}$ & $\begin{array}{c}\text { No } \\
\text { No. (\%) }\end{array}$ & $\begin{array}{c}\text { Yes } \\
\text { No. (\%) }\end{array}$ & $\begin{array}{c}\text { Total } \\
\text { No. (\%) }\end{array}$ & Statistical tests \\
\hline Total & $2500(78.2)$ & $696(21.8)$ & 3196 (100.0) & \multirow{4}{*}{$\chi^{2}=10.804, P<0.001$} \\
\hline Sex & & & & \\
\hline Males & $1250(75.9)$ & $397(24.1)$ & $1647(51.5)$ & \\
\hline Females & $1250(80.7)$ & $299(19.3)$ & $1549(48.5)$ & \\
\hline Age (years) & & & & \multirow{6}{*}{$\begin{array}{c}\chi^{2}=17.919,(r=-0.007, \\
P=0.706)\end{array}$} \\
\hline $18-29$ & $758(78.6)$ & $206(21.4)$ & $964(30.2)$ & \\
\hline $30-39$ & $730(79.8)$ & $185(20.2)$ & $915(28.6)$ & \\
\hline $40-49$ & $457(72.8)$ & $170(27.1)$ & $627(19.6)$ & \\
\hline $50-59$ & $208(76.8)$ & $63(23.2)$ & $271(8.5)$ & \\
\hline $60+$ & $347(82.8)$ & $72(17.2)$ & $419(13.1)$ & \\
\hline Education level & & & & \multirow{4}{*}{$\begin{array}{l}\chi^{2}=1.025, P<0.001 \\
(r=0.178, P<0.001)\end{array}$} \\
\hline Elementary or lower & 559 (91.0) & $55(9.0)$ & $614(19.2)$ & \\
\hline Preparatory to high school & $1285(78.4)$ & $353(21.6)$ & $1638(51.3)$ & \\
\hline Diploma and above & $655(69.4)$ & $289(30.6)$ & $944(29.5)$ & \\
\hline Monthly income $e^{a}\left(\right.$ Jordanian dinars $\left.{ }^{b}\right)$ & & & & \multirow{4}{*}{$\begin{array}{c}\chi^{2}=65.933, P=0.379 \\
(r=0.137, P<0.001)\end{array}$} \\
\hline$<300$ & $1264(84.5)$ & $231(15.5)$ & $1495(47.1)$ & \\
\hline $300-599$ & $902(73.5)$ & $325(26.5)$ & $1227(38.7)$ & \\
\hline $600+$ & $320(70.8)$ & $132(29.2)$ & $452(14.2)$ & \\
\hline
\end{tabular}

a Since 22 respondents did not wish to declare their income, the total responses of the income category were 3174.

${ }^{b} \mathrm{US} \$ 1=0.07$ Jordanian dinars.

\begin{tabular}{|c|c|c|c|c|}
\hline $\begin{array}{l}\text { Have you ever participated in a } \\
\text { clinical trial? }\end{array}$ & $\begin{array}{c}\text { No } \\
\text { No. (\%) }\end{array}$ & $\begin{array}{c}\text { Yes } \\
\text { No. (\%) }\end{array}$ & $\begin{array}{c}\text { Total } \\
\text { No. (\%) }\end{array}$ & Statistical tests \\
\hline Total & $3157(98.8)$ & $39(1.2)$ & $3196(100.0)$ & \\
\hline Sex & & & & $\chi^{2}=0.875, P=0.421$ \\
\hline Male & $1624(98.6)$ & $23(1.4)$ & $1647(51.5)$ & \\
\hline Female & $1533(99.0)$ & $16(1.0)$ & $1549(48.5)$ & \\
\hline Age (years) & & & & $\chi^{2}=3.988, P=0.408$ \\
\hline $18-29$ & $947(98.2)$ & $17(1.8)$ & $964(30.2)$ & $(r=-0.030, P=0.091)$ \\
\hline $30-39$ & $904(98.7)$ & $12(1.3)$ & $915(28.6)$ & \\
\hline $40-49$ & $622(99.2)$ & $5(0.8)$ & $627(19.6)$ & \\
\hline $50-59$ & $269(99.3)$ & $2(0.7)$ & $271(8.5)$ & \\
\hline $60+$ & $414(99.0)$ & $4(1.0)$ & $418(13.1)$ & \\
\hline Education level & & & & $\chi^{2}=2.518, P=0.284$ \\
\hline Elementary or lower & $608(99.0)$ & $6(1.0)$ & $614(19.2)$ & $(r=0.025, P=0.164)$ \\
\hline Preparatory to high school & $1621(99.0)$ & $17(1.0)$ & $1638(51.3)$ & \\
\hline Diploma and above & $928(98.3)$ & $16(1.7)$ & $944(29.5)$ & \\
\hline Monthly income $e^{a}$ (Jordanian dinars $\left.{ }^{b}\right)$ & & & & $\chi^{2}=1.272, P=0.529$ \\
\hline$<300$ & 1478 (98.9) & $17(1.1)$ & $1495(47.1)$ & $(r=0.015, P=0.387)$ \\
\hline $300-599$ & $1213(98.9)$ & $14(1.1)$ & $1227(38.7)$ & \\
\hline $600+$ & $444(98.2)$ & $8(1.8)$ & $452(14.2)$ & \\
\hline
\end{tabular}

a Since 22 respondents did not wish to declare their income, the total responses of the income category were 3174 . ${ }^{b} \mathrm{US} \$ 1=0.07$ Jordanian dinars. 


\section{Willingness to participate in clinical trials}

The willingness of respondents to participate in clinical trials was investigated. Those who indicated that it was "very likely" or "likely" that they would be willing to participate constituted $3.6 \mid \%$ and $21.1 \%$ of respondents respectively (Table 3). Most respondents were unwilling to participate in clinical trials: $35.0 \%$ and $40.3 \%$ of survey participants respectively indicated that it would be unlikely or very unlikely that they would agree to participate. Significantly more women than men said they would be very likely to agree to participate in clinical trials $(4.3 \%$ versus $2.9 \%$ respectively, $P=0.025$ ). At the same time significantly more women than men said they would be very unlikely to agree to participate in clinical trials $(42.0 \%$ and $38.7 \%$ respectively, $P=0.025)$. Willingness to participate in clinical trials was also significantly associated with age $(P<0.001)$ but without a clear trend $(r=0.031, P=0.081)$. Respondents between the ages of 40 and 49 years were very likely (4.0\%) or likely $(26.5 \%)$ to be willing to participate in clinical trials. Decreasing income was significantly correlated with a higher likelihood of willingness to participate in clinical trials $(r=0.071$,
$P<0.001)$. On the other hand, no significant correlation was found between educational level and willingness to participate in clinical trials. Perceived health status was significantly associated with willingness to participate in clinical trials; those who perceived their health status as bad or satisfactory were less likely to be willing to participate in clinical trials $(P<0.001)$.

\section{Reasons for not participating in clinical trials}

The 2406 respondents who said they would be unlikely or very unlikely to agree to participate in clinical trials were given the chance to explain their reason(s) why (Table 4). The most common reason for not wanting to participate in a clinical trial was its perceived high risk to their health (61.1\% of participants). This was followed by not being convinced about the outcome and benefits of clinical trials $(29.7 \%)$.

\section{Discussion}

Based on feedback from both patients and clinical research associates, the reasons influencing participation in clinical trials have been classified into physician-relat-

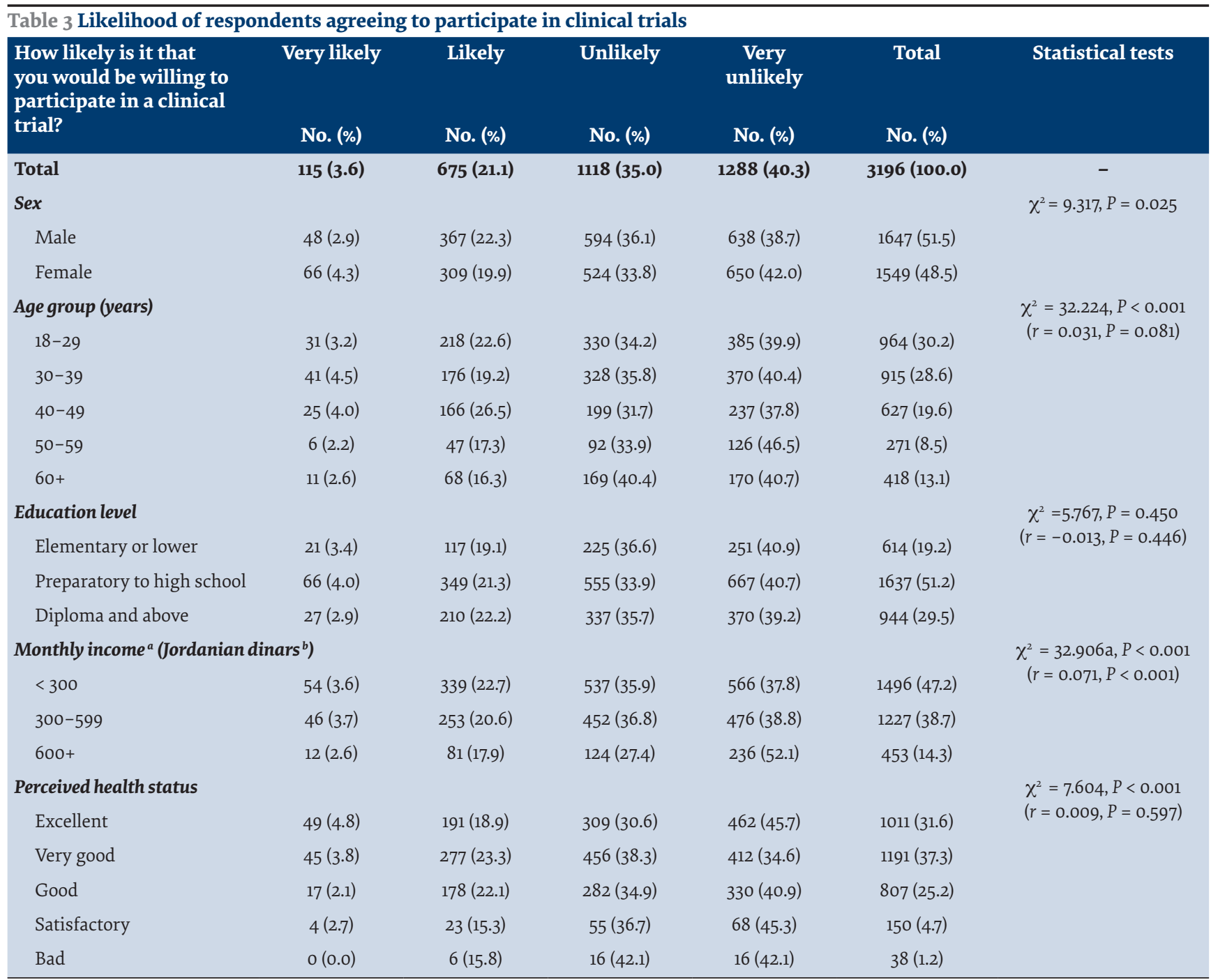

${ }^{a}$ Since 22 respondents did not wish to declare their income, the total responses of the income category were 3174. ${ }^{b} \mathrm{US} \$ 1=0.07$ Jordanian dinars. 


\begin{tabular}{lc}
\hline Table 4 Participants' reasons for not participating in clinical trials & No. (\%) \\
\hline Reason & $1688(61.1)$ \\
\hline Risk to my health & $819(29.7)$ \\
Not convinced about the outcome and benefits of clinical trials & $85(3.1)$ \\
Old age and poor health status & $71(2.6)$ \\
Have not thought about this & $46(1.7)$ \\
No time & $27(1.0)$ \\
Religious and cultural barriers & $14(0.5)$ \\
Lack of knowledge & $12(0.4)$ \\
Dislike of hospitals and physicians & $2762(100.0)$ \\
Total responses & \\
\hline
\end{tabular}

ed, patient-related and system-related (19). Our study focused on public understanding of and attitude to clinical trials. Our results clearly show a lack of understanding of what clinical trials are, with a significant difference according to sex, age, education and income. Only $21.8 \%$ of our sample had any knowledge of clinical trials, which is comparable to that reported in Oman, where $31.3 \%$ of survey respondent knew what the term meant (10). Jordanian men appeared to be more knowledgeable of clinical trials than women. In addition, more respondents aged 40-49 years knew of clinical trials. It is probable that the lower awareness in younger age groups is because of a lack of life experiences, whereas poorer education could be the reason why older people were the least knowledgeable. Moreover, there was a significant association between both increasing educational level and increasing income, and increasing knowledge of clinical trials. This is similar to the results found in a study in the USA, which concluded that low education levels and low income were predictors of lack of awareness of clinical trials, and were associated with lower participation in trials (20).

A study in 2004 reported that enrolment of cancer patients in clinical trials in the USA was low overall and ranged from $0.5 \%$ to $3 \%$ depending on ethnicity and age group (12). These percentages are similar to the actual participation of individuals in Jordan in clinical trials, which was indicated by only $1.2 \%$ of respondents. Whereas the American study found a strong inverse correlation between age and enrolment (12), we did not find any correlation between willingness to participate in clinical trials and age, education, sex and income. The rate of participation in clinical trials is expected to be higher among those in need, such as cancer patients. In fact, one study showed that only $3 \%$ of cancer survivors had participated in cancer clinical trials but a large proportion of cancer survivors (65\%) would have participated in trials had they known about them (21). A study in Saudi Arabia also showed that $61 \%$ of the cancer patients and their family members were aware of clinical trials and 58\% were willing to take part in them (22).

We found that significantly more men than women were willing to participate in clinical trials which is similar to the various studies in the USA $(11,12)$. However, women in Jordan were more decisive in their responses with a slightly higher percentage answering very likely or very unlikely than men. People more than 50 years were the least likely to be willing to participate in clinical trials, which is similar to other reports $(23,24)$. Income level was an important factor in our study; respondents in higher income levels were significantly less likely to be willing to participate in clinical trials. Interestingly, this is in contrast to other studies in which lower rates of participation were reported in people with lower incomes $(13,25)$. In Jordan, this difference may be due to perceived better access to health care and certain benefits (e.g. monetary compensation) among the lower income groups if they participate in clinical trials. In addition, although old age and poor health status were associated with unwillingness to enrol in a clinical trial, only $3.1 \%$ of our participants gave this as a reason for not participating in a clinical trial.

When asked about the reasons for not participating, the most common reason given by the participants was concern of an adverse effect on health, which accounted for $61.1 \%$ of responses. This was followed by not being convinced about the outcome and benefits of clinical trials (29.7\%). These responses are in line with other studies. For example, concern of health risks was the main reason for lack of participation in clinical trials among African Americans (26). In a Danish study, fear of adverse effects from treatments in clinical trials was the most common reason for not participating (27). Participant-related factors that affect participation in clinical trials include, but are not limited to, demographic characteristics, lack of interest, time and transportation, physical limitations, and fear of emotional effect (28). Research-related factors may also influence the decision to participate in a clinical trial, such as random assignment and the effect on the participants' daily routine. Finally, lack of trust in physicians was reported in a pilot study across the Middle East, with many participants believing that doctors conduct studies without consent and that withdrawal from a study would lead to a poorer level of health care services provided (29).

The fact that the top three reasons why respondents in our study were not willing to participate in clinical trials are related to a lack of understanding of clinical trials and their importance highlights the need to raise 
awareness and educate the public in Jordan. One way to do this is to incorporate the concept of clinical trials in the Jordanian educational curricula. This will ensure that future generations are fully aware of the importance of clinical trials and what they entail. More importantly, the role of the media and mass communication must be recognized and directed to the issue. Television programmes are reported to be the most important way to convey medical-related information in Jordan (30). Furthermore, physicians play an important role in the recruitment of individuals in clinical trials. Participation of cancer survivors in clinical trials was found to be directly related to physician involvement (21). Thus, it is important to examine the factors that influence physician involvement and the health care system. The Saudi Arabian study on public perception of clinical trials, for example, noted that physician-patient interaction is a key factor in determining willingness to participate; $74 \%$ of Saudi Arabians interviewed reported that they would have to consult a physician involved in their care before agreeing to participate in a clinical trial (9). Therefore, it is important to increase physician involvement in the recruitment process of clinical trials as well as holding information sessions about clinical trials and the ethics of them. The need for such approaches in the Middle East is highlighted by another study in Saudi Arabia where clinicians had limited knowledge of clinical trials, several misconceptions about them and little time to conduct them (31).

Jordan and other countries in the Middle East and North Africa are underrepresented in the percentage of clinical trials conducted globally (32), so there is room for improvement. The presence of qualified health care professionals, well-equipped health care centres and institutions, and well-established regulatory laws make Jordan an ideal place to conduct clinical trials (33). Jordan was the first Arab country in the Middle East and North Africa that enacted clinical trial regulations in 2001. The Clinical Studies Division of the Drug Directorate at the Jordan Food and Drug Administration was founded in 2004 and currently oversees all clinical trials conducted in Jordan (34).

A strength of our study is the involvement of a representative sample of the Jordanian population. In addition, our results could reflect views of Middle Eastern people in general because of the cultural and religious similarities. However, being a self-report interview study, individuals may be reluctant to explicitly state their views objectively and might rather provide biased, socially acceptable responses. Furthermore, this survey was part of a long questionnaire with possibly insufficient time for respondents to think about this new concept. Nevertheless, our results highlight the need to establish awareness campaigns to promote public involvement in clinical trials.

Funding: This work was supported by the Arab Fund for Economic and Social Development (AFESD). The knowledge attitude and practice survey was implemented by King Hussein Institute for Biotechnology and Cancer under the National Life Science Research and Biotechnology Promotion Initiative in Jordan.

Competing interests: None declared.

\section{Essais cliniques en Jordanie : connaissance, attitudes connexes et participation mesurées par une enquête en population \\ Résumé}

Contexte : Les essais cliniques sont importants pour améliorer les soins de santé publique. Cependant, le recrutement des participants pour ces essais peut s'avérer difficile.

Objectifs : La présente étude visait à évaluer la connaissance publique des essais cliniques et la volonté d'y participer en Jordanie, et à examiner les caractéristiques sociodémographiques associées, ainsi que les raisons expliquant leur réponse négative.

Méthodes : Les questions ont été posées dans le cadre d'une enquête en population représentative menée en 2011 auprès de 3196 Jordaniens. Lors d'un entretien conduit à domicile, des questions ont été posées aux participants sur leurs caractéristiques sociodémographiques, leur connaissance des essais cliniques et leur participation à ces derniers.

Résultats : Seuls $21,8 \%$ des personnes interrogées savaient ce qu'est un essai clinique, et 1,2\% d'entre elles avait déjà participé à ce type d'essai. Près de $25 \%$ des personnes interrogées ont signifié leur volonté de participer à un essai clinique. Les hommes étaient significativement plus nombreux $(24,1 \%)$ que les femmes $(19,3 \%)$ à savoir ce qu'est un essai clinique $(p<0,001)$. À l'inverse, davantage de femmes $(4,3 \%)$ que d'hommes $(2,9 \%)$ ont indiqué être très susceptibles d'accepter de participer à des essais cliniques. Les personnes âgées de 40 à 49 ans avaient une meilleure connaissance des essais cliniques et une plus grande volonté d'y participer que les autres groupes d'âge. Les revenus étaient associés de façon positive à la connaissance des essais cliniques, mais de façon négative à la volonté d'y participer. Un niveau d'éducation élevé avait une corrélation positive avec la connaissance des essais cliniques et la volonté d'y participer. Les principaux motifs de non - participation aux essais étaient l'inquiétude concernant le risque pour la santé personnelle $(61,6 \%$ ) et le fait de ne pas être convaincu des résultats et du bénéfice des essais cliniques $(29,7 \%)$.

Conclusion : Le faible degré de connaissance et de volonté de participer à des essais cliniques indique que des stratégies de sensibilisation du grand public à la nature et à l'importance des essais cliniques sont nécessaires. 


$$
\begin{aligned}
& \text { المعلومات والاتجاهات الخاصة بالتجارب السريرية، والمو اقف تجاهها، والمشار كة فيها في الأردن: مسح سكاني } \\
& \text { مأمون أهر ام، علاء فركوح، مرح حداد، زينة القلعجي، أحمد يانس }
\end{aligned}
$$

الخلفية: تكتسي التجارب السريرية أهمية من أجل تحسين الرعية الصحية العامة. وبالرغم من ذلك، فإن اختيار المشاركين لإجر اء تلك التجارب قد تغلب عليه بعض الصعوبة.

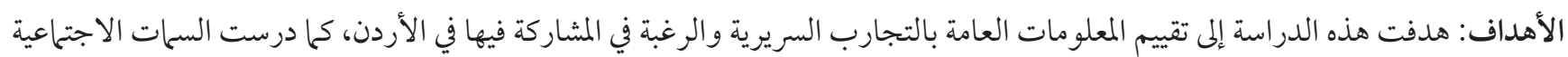

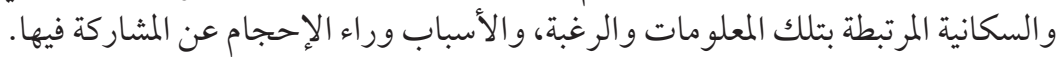

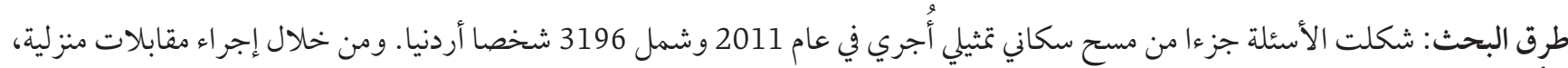

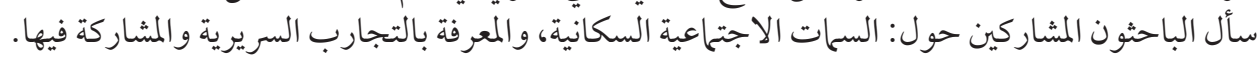

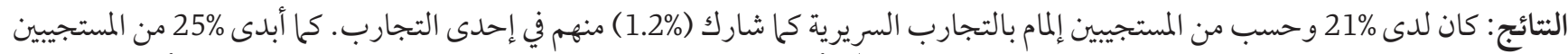

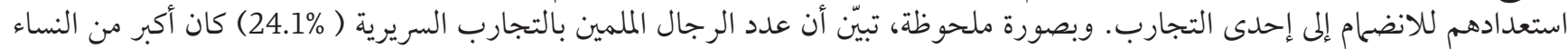

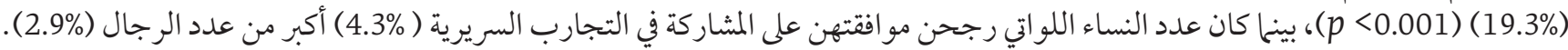

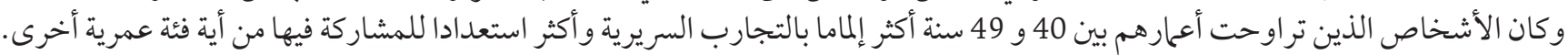

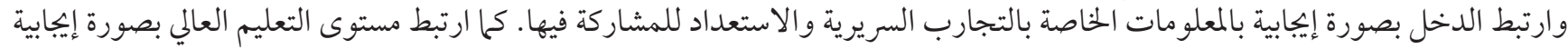

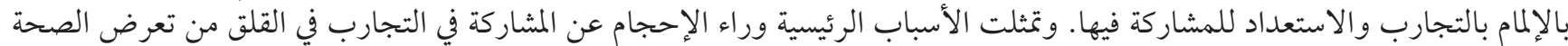

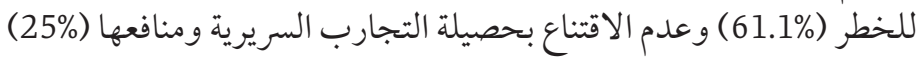

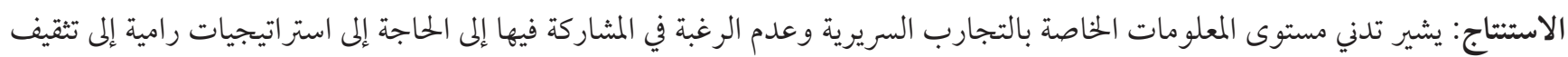

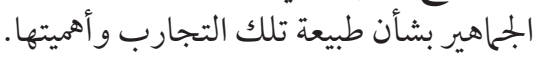

\section{References}

1. Hart D. BioNJ economic impact study of clinical trials activity in New Jersey. BioNJ; 2016 (https://bionj.org/wp-content/uploads/2016/06/Economic-Impact-of-Clinical-Trials-Booklet-2016_FINAL-1.pdf, accessed 21 November 2019).

2. Kalo Z, Antal J, Penzes M, Pozsgay C, Szepezdi Z, Nagyjanosi L. Contribution of clinical trials to gross domestic product in Hungary. Croat Med J. 2014;55(5):446-51. https://doi.org/10.3325/cmj.2014.55.446

3. KPMG. Impact and value of the NIHR Clinical Research Network. KPMG; 2019. (https://www.nihr.ac.uk/documents/partners-and-industry/NIHR_Impact_and_Value_report_ACCESSIBLE_VERSION.pdf, accessed 21 November 2019).

4. Yancy CW. Heart failure in African Americans: a cardiovascular enigma. J Card Fail. 2000;6(3):183-6. https://doi.org/10.1054/ jcaf.2000.17610

5. Shekelle PG, Rich MW, Morton SC, Atkinson CS, Tu W, Maglione M et al. Efficacy of angiotensin-converting enzyme inhibitors and beta-blockers in the management of left ventricular systolic dysfunction according to race, gender, and diabetic status: A meta-analysis of major clinical trials. J Am Coll Cardiol. 2003;41(9):1529-38. https://doi.org/10.1016/s0735-1097(03)00262-6

6. Ellis PM, Butow PN. Focus group interviews examining attitudes to randomised trials among breast cancer patients and the general community. Aust N Z J Public Health. 1998;22(5):528-31. https://doi.org/10.1111/j.1467-842x.1998.tbo1432.x

7. Asai A, Ohnishi M, Nishigaki E, Sekimoto M, Fukuhara S, Fukui T. Focus group interviews examining attitudes toward medical research among the Japanese: a qualitative study. Bioethics. 2004;18(5):448-70. https://doi.org/10.1111/j.1467-8519.2004.00409.x

8. Madsen SM, Mirza MR, Holm S, Hilsted KL, Kampmann K, Riis P. Attitudes towards clinical research amongst participants and nonparticipants. J Intern Med. 2002;251(2):156-68. https://doi.org/10.1046/j.1365-2796.2002.00949.x

9. Al-Tannir MA, El-Bakri N, Abu-Shaheen AK. Knowledge, attitudes and perceptions of saudis towards participating in clinical trials. PLoS One. 2016;11(2):e0143893. https://doi.org/10.1371/journal.pone.0143893

10. Al-Lawati H, Al-Baimani K, Al-Zadjali M, Al-Obaidani N, Al-Kiyumi Z, Al-Khabori MK. Knowledge and attitudes towards clinical trial participation in Oman: a cross-sectional study. Sultan Qaboos Univ Med J. 2018;18(1):e54-e6o. https://doi.org/10.18295/ squmj.2018.18.01.009.

11. Duma N, Vera Aguilera J, Paludo J, Haddox CL, Gonzalez Velez M, Wang Y et al. Representation of minorities and women in oncology clinical trials: review of the past 14 years. J Oncol Pract. 2018;14(1):e1-e10. https://doi.org/10.1200/JOP.2017.025288.

12. Murthy VH, Krumholz HM, Gross CP. Participation in cancer clinical trials: race-, sex-, and age-based disparities. JAMA. 2004;291(22):2720-6. https://doi.org/10.1001/jama.291.22.2720

13. Ford JG, Howerton MW, Lai GY, Gary TL, Bolen S, Gibbons MC et al. Barriers to recruiting underrepresented populations to cancer clinical trials: A systematic review. Cancer. 2008;112(2):228-42. https://doi.org/10.1002/cncr.23157

14. Ahmad M, Gamal, E. Al Othman A., Nasrallah E. Knowledge, attitudes and practices towards cancer prevention and care in Jor- 
dan. Amman: King Hussein Institute for Biotechnology and Cancer; 2014.

15. Ahram M, Othman A, Shahrouri M. Public Perception Towards Biobanking in Jordan. Biopreserv Biobank. 2012;10(4):361-5. https://doi.org/10.1089/bio.2012.0010.

16. Jaghbir, M, Shreif, S, Ahram, M. Pattern of cigarette and waterpipe smoking in the adult population of Jordan. East Mediterr Health J. 2014;20(9):529-37.

17. Ahram M, Soubani M, Abu Salem L, Saker H, Ahmad M. Knowledge, attitudes, and practice regarding genetic testing and genetic counselors in Jordan: a population-based survey. J Genet Couns. 2015;24(6):1001-10. https://doi.org/10.1007/s10897-015-9839-3

18. Hesse, Bradford, and Moser. Health Information National Trends Survey (HINTS), 2005. Ann Arbor, MI: Inter-university Consortium for Political and Social Research; 2009. https://doi.org/10.3886/ICPSR24383.v1

19. Grunfeld E, Zitzelsberger L, Coristine M, Aspelund F. Barriers and facilitators to enrollment in cancer clinical trials: qualitative study of the perspectives of clinical research associates. Cancer. 2002;95(7):1577-83. https://doi.org/10.1002/cncr.10862

20. Brown M, Moyer A. Predictors of awareness of clinical trials and feelings about the use of medical information for research in a nationally representative US sample. Ethn Health. 2010;15(3):223-36. https://doi.org/10.1080/13557851003624281

21. Comis RL, Miller JD, Colaizzi DD, Kimmel LG. Physician-related factors involved in patient decisions to enroll onto cancer clinical trials. J Oncol Pract. 2009;5(2):50-6. https://doi.org/10.1200/JOP.0922001

22. Bazarbashi S, Hassan A, Eldin AM, Soudy H, Hussain F. Awareness and perceptions of clinical trials in cancer patients and their families in Saudi Arabia. J Cancer Educ. 2015;30(4):655-9. https://doi.org/10.1007/s13187-015-0797-0

23. Lewis JH, Kilgore ML, Goldman DP, Trimble EL, Kaplan R, Montello MJ et al. Participation of patients 65 years of age or older in cancer clinical trials. J Clin Oncol. 2003;21(7):1383-9. https://doi.org/10.1200/JCO.2003.08.010

24. Greenwade MM, Moore KN, Gillen JM, Ding K, Rowland MR, Crim AK et al. Factors influencing clinical trial enrollment among ovarian cancer patients. Gynecol Oncol. 2017;146(3):465-9. https://doi.org/10.1016/j.ygyno.2017.06.035

25. Unger JM, Hershman DL, Albain KS, Moinpour CM, Petersen JA, Burg K et al. Patient income level and cancer clinical trial participation. J Clin Oncol. 2013;31(5):536-42. https://doi.org/10.1200/JCO.2012.45.4553

26. Gadegbeku CA, Stillman PK, Huffman MD, Jackson JS, Kusek JW, Jamerson KA. Factors associated with enrollment of African Americans into a clinical trial: results from the African American study of kidney disease and hypertension. Contemp Clin Trials. 2008;29(6):837-42. https://doi.org/10.1016/j.cct.2008.06.001

27. Madsen SM, Holm S, Riis P. Attitudes towards clinical research among cancer trial participants and non-participants: an interview study using a grounded theory approach. J Med Ethics. 2007;33(4):234-40. https://doi.org/10.1136/jme.2005.015255

28. Gul RB, Ali PA. Clinical trials: the challenge of recruitment and retention of participants. J Clin Nurs. 2010;19(1-2):227-33. https:// doi.org/10.1111/j.1365-2702.2009.03041.x

29. Hifnawy T, Kobrosly S, Edwards H, Anwar M, Zahran D, Silverman H. Patients' attitudes and perceptions regarding research and their rights: a pilot survey study from the Middle East. East Mediterr Health J. 2017;23(7):461-8. https://doi. org/10.26719/2017.23.7.461

30. Akhu-Zaheya LM, Jagbir MT, Othman A, Ahram M. Media use for seeking health/cancer-related information: Findings from knowledge, attitudes and practices towards cancer prevention and care survey in Jordan. Int J Nurs Pract. 2014;20(6):608-15. https://doi.org/10.1111/ijn.12196

31. Al-Tannir MA, Katan HM, Al-Badr AH, Al-Tannir MM, Abu-Shaheen AK. Knowledge, attitudes, practices and perceptions of clinicians towards conducting clinical trials in an Academic Tertiary Care Center. Saudi Med J. 2018;39(2):191-6. https://doi. org/10.15537/smj.2018.2.21093

32. Nair SC, Ibrahim H, Celentano DD.Clinical trials in the Middle East and North Africa (MENA) Region: grandstanding or grandeur? Contemp Clin Trials. 2013;36(2):704-10. https://doi.org/10.1016/j.cct.2013.05.009

33. Shafout E, Mahrouq SA. Clinical trials in Jordan: current status opportunities. Clin Res. December 2014. https://doi.org/10.14524/ CR-14-0038

34. Arouri A, Russmann D. The evolving clinical research environment in Jordan. Regul Rapporteur. 2015;12(4):16-21 (https://www. researchgate.net/publication/272083820_The_evolving_clinical_research_environment_in_Jordan, accessed 21 November 2019). 